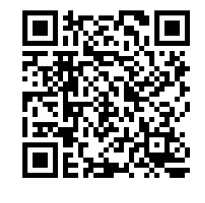

Keywords: Sewage sludge Coconut fiber Forest nursery Solid wastes Forest restoration

Historic: Received 03/06/2018 Accepted 13/10/2018

Correspondence: j_makh@hotmail.com

Jorge Makhlouta Alonso ${ }^{\mathrm{a}+}$, Alan Henrique Marques de Abreu², Lucas Amaral de Melo ${ }^{3}$, Paulo Sérgio dos Santos Leles ${ }^{\mathrm{lb}}$, Gerhard Valkinir Cabreiralc

\title{
BIOSOLIDS AS SUBSTRATE FOR THE PRODUCTION OF CEIBA SPECIOSA SEEDLINGS
}

ALONSO, J. M.; ABREU, A. H. M.; MELO, L. A.; LELES, P. S.S.; CABREIRA, G.V. Biosolids as substrate for the production of Ceiba speciosa seedlings. CERNE, v. 24, n. 4, p. 420-429, 2018.

\section{HIGHLIGHTS}

Seedlings showed higher growth in substrates with $50-100 \%$ of biosolids.

In substrates with $50-100 \%$ of biosolids seedlings reached quality to be outplanted.

The substrate composed only by biosolids was viable to produce forest seedlings.

Thus, the use of biosolids in forest seedling production can be encouraged.

\section{ABSTRACT}

Biosolids is a problematic residual issue in Brazil and other developing countries, where it is common to discard this material in landfills and/or open dumps. However, biosolids can be recycled in agricultural and forestry activities, considering they have high contents of organic matter and nutrients. Therefore, their application in substrates to produce forest seedlings can be beneficial. The scope of this study is to evaluate substrates with different proportions of biosolids and coconut fiber in the growth and quality of seedlings of Ceiba speciosa (A. St.-Hil.) Ravenna, a native species from South America that is largely used for landscaping and forest restoration. There were studied substrates with proportions varying between 25 to $100 \%$ of biosolids and 75 to $0 \%$ of coconut fiber to produce seedlings in containers (plastic tubes with $280 \mathrm{~cm}^{3}$ ). At 120 days after sowing, it was measured the growth, biomass and quality of the seedlings. In general aspects, the higher the proportion of biosolids in the substrate, the higher were the growth, biomass and quality. The biosolids favored the growth in shoot height and biomass more than in diameter and root biomass. Considering the positive results and the possibility of recycling biosolids, it is recommended the use of substrates containing from 50 to $100 \%$ of biosolids to produce Ceiba speciosa seedlings in $280 \mathrm{~cm}^{3}$ plastic tubes.

' Federal Rural University of Rio de Janeiro, Seropédica, Rio de Janeiro, Brazil - ORCID: 0000-0002-66 |4-7| 4Xa, 0000-0002-8393-6095', 0000-0003-2103-3103c 


\section{INTRODUCTION}

The economical and populational expansion of South America have promoted significant changes in natural environments within the continent, and among the most affected areas are those under the Atlantic Forest biome. According to SOS Mata Atlântica and INPE (2018) this biome has only $12.4 \%$ of its original forest area, demanding concrete actions for its conservation and restoration. In this context, the seedling plantation has been one of the most used techniques for the Atlantic Forest restoration (Moraes et al, 20I3; Klippel et al., 20I5). Considering this demand, there is a need to produce seedlings in large quantities and with quality enough to survive the adverse conditions of the planting site.

Seedlings of tree species can be produced in bareroot or in containers, in tropical countries and for broadleaf species the production in containers is more usual (Carneiro, 1995). The production of seedlings in containers, such as polyethylene bags and polypropylene tubes, demand the preparation of a substrate, which must have adequate physical and chemical characteristics and its components must be available locally with low acquisition costs (Gomes and Paiva, 2006).

The management of solid urban wastes and the deficiency in basic sanitation are recurrent environmental problems in Brazilian cities, as well as in other metropolitan areas of developing countries. Comprising both issues, there is a need to manage the solid waste resulting from treatment of sewage, sewage sludge, which in Brazil and other developing countries is commonly discarded in sanitary landfills, contributing to the pressure of depletion of landfills capacity in metropolitan areas (Abreu et al., 2017). Although sewage treatment rates are still low in these countries, growing demands from society and public authorities are indicating a significant increase in sewage treatment soon and, consequently, an increase in sludge production (Andreoli et al., 20I4).

When treated and stabilized, the sewage sludge can be referred to as biosolids, if it presents chemical and physical characteristics that are compatible with their productive use (Andreoli et al., 20l4). Due to the high levels of organic matter and nutrients, biosolids can be recycled through the application in agricultural and forestry activities, which consists in a more environmentally sustainable destination compared to landfill disposal (Abreu et al., 2017).

As an alternative of recycling biosolids in forestry, their application as a component of substrates to produce seedlings of Atlantic Forest species has been shown to be viable (Trigueiro and Guerrini, 20I4; Cabreira et al.,
2017). For the utilization of biosolids in the substrate, it is necessary to know the physical and chemical characteristics of each batch of the material, according to which it is possible to study and determine the adequate proportions that biosolids can be applied aiming higher growth and quality of seedlings.

The Ceiba speciosa (A. St.-Hil.) Ravenna, known as paineira in Brazil, palo borracho in other South America countries and silk floss tree in English, is a deciduous tree species, native from Atlantic Forest, largely used in forest restoration and in landscaping projects, considering the shape of its trunk, the format of its crown and beauty of its flowering (Carvalho, 2003).

Thus, the objective of this work was to evaluate substrates with different proportions of biosolids and coconut fiber in the growth and quality of seedlings of Ceiba speciosa (A. St.-Hil.) Ravenna.

\section{MATERIAL AND METHODS}

The study was conducted from June to November 2016 at the Forest Nursery of the Federal Rural University of Rio de Janeiro, located in the city of Seropédica, Rio de Janeiro state, Brazil. The studied species was Ceiba speciosa (A. St.-Hil.) Ravenna, locally known as paineira. According to the Köppen-Geiger classification, the local climate can be classified as Aw, which means tropical with dry winter and rainy summer. According to the last 20 years' data of the weather station of the Agricultural Research Company of Rio de Janeiro (PESAGRO-RJ), the mean annual rainfall is $1,245 \mathrm{~mm}$, with driest period in June, July and August, and water excess in December, January and February. The mean annual temperature is $23.7^{\circ} \mathrm{C}$, February is the hottest month with $27.0^{\circ} \mathrm{C}$ mean and July is the coldest with $20.6^{\circ} \mathrm{C}$ mean. The mean time of insolation is $2,527 \mathrm{~h}$, the mean annual evaporation is I,576 $\mathrm{mm}$ and the relative air humidity is $69 \%$.

The experiment was conducted using completely randomized design with four treatments, each one with four replications of twelve seedlings, totaling 48 seedlings per treatment. The treatments consisted in substrates with different proportions of biosolids and coconut fiber, being them: TI: $25 \%$ of biosolids (BIO) and $75 \%$ coconut fiber (CF); T2: $50 \% \mathrm{BIO}$ and $50 \%$ CF; T3: $75 \%$ $\mathrm{BIO}$ and $25 \% \mathrm{CF}$; and $\mathrm{T} 4$ : $100 \% \mathrm{BIO}$.

The coconut fiber used to compose the substrates was bought locally in retail. The fiber was washed before its commercialization, aiming to reduce the salinity that is commonly high in this material and can be problematic.

The biosolids used in the experiment was provided by the Water and Sewage State Company of 
Rio de Janeiro (CEDAE), coming from the Wastewater Treatment Plant (WWTP) of Alegria, located in the Caju neighborhood, Rio de Janeiro city, Rio de Janeiro state, Brazil. This WWTP receives sewage from urban commercial and residential areas and performs the treatment using the activated sludge process. The sludge generated during the treatment is thickened in centrifuge and then dried and stabilized in open air semipermeable drying beds, where it stays for approximately 90 days, until it reaches at least $30 \%$ of humidity.

The biosolids used in the study were evaluated accordingly to the Brazilian law, the Resolution of National Environment Council (CONAMA) n 375/2006, which demands to test each biosolid batch for heavy metals content (Table I) and microbiological indicators (Table 2). It was observed that the levels of these parameters were bellow the required by the legislation for the material used in the present study.

After assembling the experiment, samples of each substrate (treatment) were collected and sent for chemical analysis to determine the total Kjeldahl nitrogen, available macronutrients content $(\mathrm{P}, \mathrm{K}, \mathrm{Ca}$ and $\mathrm{Mg}$ ), cation exchange capacity (CEC) and organic matter (OM), according to the methodologies proposed by Embrapa (2009).

For the determination of the physical characteristics of the substrate, ten $56 \mathrm{~cm}^{3}$ plastic tubes were used per treatment, each consisting in one replication. The tubes were submitted to water saturation and after that it was

TABLE I Heavy metals content in the biosolid of the WWTP of Alegria, Rio de Janeiro - RJ in comparison with the maximum allowed value in the Resolution of CONAMA n 375/2006.

\begin{tabular}{|c|c|c|c|c|c|c|c|c|c|c|c|}
\hline & As & $\mathrm{Ba}$ & $\mathrm{Cd}$ & $\mathrm{Pb}$ & $\mathrm{Cu}$ & $\mathrm{Cr}$ & $\mathrm{Hg}$ & Mo & $\mathrm{Ni}$ & $\mathrm{Se}$ & $\mathrm{Zn}$ \\
\hline & \multicolumn{11}{|c|}{ 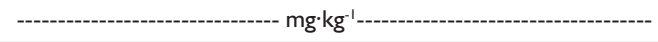 } \\
\hline CONAMA & 41 & 1300 & 39 & 300 & 1500 & 1000 & 17 & 50 & 420 & 100 & 2800 \\
\hline $\begin{array}{l}\text { WWTP } \\
\text { Alegria }\end{array}$ & $<2,6$ & 157 & $<0,2$ & 197 & 267 & 70 & $<0,03$ & 22,6 & 40,2 & $<5,9$ & 681 \\
\hline
\end{tabular}

TABLE 2 Concentration of pathogenic microorganisms in the biosolid of the WWTP of Alegria, Rio de Janeiro - RJ in comparison with the maximum allowed value in the Resolution of CONAMA n ${ }^{\circ}$ 375/2006.

\begin{tabular}{|c|c|c|c|}
\hline Parameter & Units & CONAMA & WWTP Alegria \\
\hline $\begin{array}{l}\text { Thermotolerant } \\
\text { Coliforms }\end{array}$ & MPN $g^{-1}$ & $<1000$ & $<0,04$ \\
\hline $\begin{array}{l}\text { Viable Helminth } \\
\text { Eggs }\end{array}$ & Eggs $g^{-1}$ & $<0,25$ & $<0,0$ I \\
\hline Salmonella sp. & $\begin{array}{c}\text { Present/absent } \\
\text { in } 10 \mathrm{~g}\end{array}$ & Absent & Absent \\
\hline
\end{tabular}

MPN: most probable number done the first weighing. After one hour of draining with the bottom of the recipient open and 12 hours with the bottom partially blocked, the tubes were weighted another time. The drained substrate was transferred to aluminum capsules that were oven dried at $65^{\circ} \mathrm{C}$ for 96 hours and after that they were weighted for the last time. With data obtained in each weighing the parameters density, micro and macroporosity and water retention capacity were calculated.

As containers for seedlings production, there were used plastic tubes with $280 \mathrm{~cm}^{3}$ of volume, which were filled with the substrate of the different treatments. The sowing was done directly in the containers, with seeds collected locally in forest fragments adjacent to the nursery. The tubes were placed in suspended trays with 56 cells each. At 45 days after sowing, when seedlings were nearly $15 \mathrm{~cm}$ high, they were rearranged in the trays for a density of $50 \%$ occupancy, thus reducing the competition between seedlings for light and facilitating the arrival of irrigation water to the substrate. All the seedlings production process was conducted in full sunlight. The irrigation was done with sprinklers twice a day. At the last 15 days of seedlings production, irrigation was done only once per day, always in the end of the afternoon, for hardening the seedlings.

The shoot height $(H)$ and root collar diameter $(D)$ of seedlings were measured monthly, from 30 until 120 days after sowing. At the last evaluation, with 120 days, there were selected four seedlings of each replication ( 16 per treatment), with shoot height near the mean value, for measuring the biomass. Thus, the shoot and root of seedlings were separated, placed in identified paper bags and allocated inside a forced air oven at $65^{\circ} \mathrm{C}$ for 72 hours, then the material was weighted in a precision scale for determining the shoot dry matter (SDM), root dry matter (RDM) and by the sum of them the total dry matter (TDM).

With the all the data collected some quality parameters were calculated: shoot height / root collar diameter $(H / D)$; shoot height / shoot dry mass (H/SDM); shoot dry mass / root dry mass (SDM/RDM) and the Dickson Quality Index (IQD).

Once shoot dry matter was weighted, the four plants of each replication were milled using a knife mill and gathered to form a composite sample for each replication. The material of each replication was identified, placed in covered plastic recipients and sent to macronutrients chemical analysis. It was evaluated the total contents of $\mathrm{N}, \mathrm{P}, \mathrm{K}, \mathrm{Ca}$ and $\mathrm{Mg}$ in plants tissues according to the methodology proposed by Embrapa (2009). 
The data normality was checked with the Lilliefors test and the homogeneity of variances with the Cochran test for each parameter evaluated. There was no necessity of data transformation. Regression analyses were conducted between seedlings production time and shoot height, as well as between production time and root collar diameter. Data from all variables measured at 120 days after sowing were submitted to analysis of variance and when significance was detected the Tukey test was performed, considering the probability of $5 \%$. For all statistical analyses it was used the software Sistema para Análises Estatísticas e Genéticas (SAEG, 2007).

\section{RESULTS}

The macronutrients content augmented with increasing proportions of biosolids in the substrate, except for $\mathrm{K}$, as can be observed in Table 3. The pH showed similar values between the treatments, while the organic matter decreased, and the cation exchange capacity (CEC) increased with higher proportions of biosolids in the substrate.

TABLE 3 Chemical characteristics of substrates, composed of biosolids (BIO) and coconut fiber (CF), used to produce Ceiba speciosa seedlings.

\begin{tabular}{ccccccccc}
\hline Treat. & $\mathrm{pH}$ & $\mathrm{N}$ & $\mathrm{P}$ & $\mathrm{K}$ & $\mathrm{Ca}$ & $\mathrm{Mg}$ & $\mathrm{CEC}$ & $\mathrm{OM}$ \\
\hline BIO\%:CF\% & & $\%$ & ---- & $\mathrm{mg} \cdot \mathrm{dm}^{-3}$ & ---- & --- & $\mathrm{mmolc} \cdot \mathrm{dm}^{-3}----$ & \\
\hline $25: 75$ & 5.05 & 1.30 & 366 & 687 & 58 & 29 & 152 & 53 \\
$50: 50$ & 5.12 & 1.47 & 602 & 448 & 91 & 38 & 209 & 43 \\
$75: 25$ & 5.10 & 1.87 & 636 & 279 & 141 & 50 & 270 & 45 \\
$100: 00$ & 5.11 & 2.26 & 752 & 155 & 202 & 79 & 367 & 38 \\
\hline
\end{tabular}

As verified on Table 4, the higher the proportion of biosolids, the higher was the density of the substrates. The results for macro and total porosity were slightly higher in the substrate with $100 \%$ of biosolids and similar in the others. For microporosity and water retention capacity (WRC) the results were similar between all treatments.

As it can be verified on Figure I, the growth in shoot height and root collar diameter presented linear pattern during the time seedlings were evaluated in the nursery. For shoot height it was observed that seedlings produced in substrates with higher proportions of biosolids showed

TABLE 4 Physical characteristics of substrates, composed of biosolids (BIO) and coconut fiber (CF), used to produce Ceiba speciosa seedlings.

\begin{tabular}{|c|c|c|c|c|c|}
\hline Trat & Density & MAP & MIP & PT & WRC \\
\hline BIO\%:CF\% & $\mathrm{g} \cdot \mathrm{cm}^{-3}$ & ---- & $\% \quad--$ & ------ & $\mathrm{ml} \cdot 50 \mathrm{~cm}^{-3}$ \\
\hline $25: 75$ & 0.14 & 27.5 & 44.3 & 71.8 & 22.1 \\
\hline $50: 50$ & 0.15 & 27.6 & 44.8 & 72.4 & 22.4 \\
\hline $75: 25$ & 0.22 & 27.8 & 45.0 & 72.8 & 21.1 \\
\hline $100: 00$ & 0.24 & 29.9 & 45.2 & 75.1 & 21.7 \\
\hline
\end{tabular}

MAP: macroporosity; MIP: microporosity; PT: total porosity; WRC: water retention capacity. a tendency of higher growth since the first measurement, at 30 days after sowing, which was maintained until the last measurement at I 20 days (Figure I).

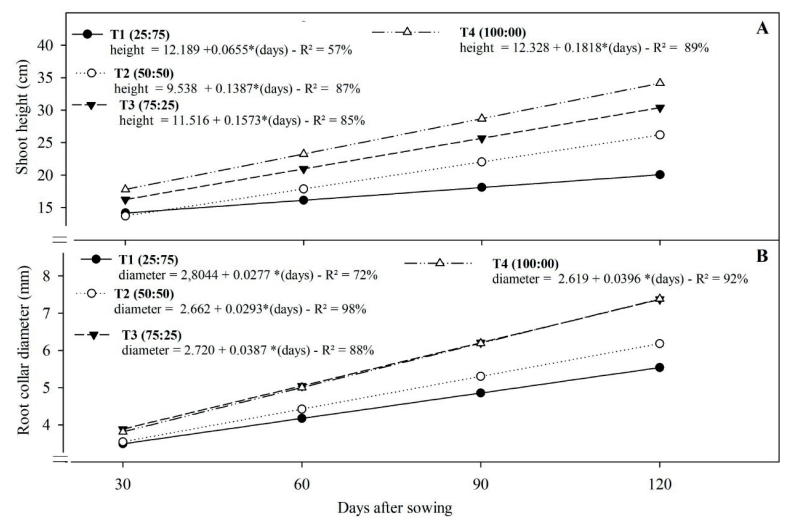

FIGURE I Growth in shoot height and root collar diameter of Ceiba speciosa seedlings produced in substrates with different proportions of biosolids and coconut fiber from 30 to 120 days after sowing.

The growth in root collar diameter (D) was similar in all treatments in the first measurement, at 30 days after sowing. From the second measurement, at 60 days after sowing, until the end of the experiment it was observed a tendency of higher root collar diameter in treatments composed by $75 \%$ or more of biosolids.

At the end of the experiment, 120 days after sowing, it was observed significant difference between treatments, in general terms, seedlings presented higher growth and biomass in substrates with higher proportions of biosolids (Table 5). Mean values of shoot height $(\mathrm{H})$, root collar diameter (RCD), shoot dry mass (SDM) and total dry mass (TDM) were higher in treatments with more biosolids (75 and $100 \%$ ). For root dry mass (RDM), the treatment with $25 \%$ of biosolids was inferior and the others did not differ.

TABLE 5 Average and standard deviation (in parentheses) of shoot height, root collar diameter, shoot dry mass (SDM), root dry mass (RDM), total dry mass (TDM), shoot proportion (SP) and roots proportion (RP) in the biomass of Ceiba speciosa seedlings, 120 days after sowing, produced in substrates with different proportions of biosolids and coconut fiber.

\begin{tabular}{|c|c|c|c|c|c|}
\hline \multirow{2}{*}{$\begin{array}{c}\text { Treatment } \\
\text { (BIO\%:CF\%) }\end{array}$} & $\mathrm{H}$ & RCD & SDM & RDM & TDM \\
\hline & $(\mathrm{cm})$ & $(\mathrm{mm})$ & \multicolumn{3}{|c|}{--------------- g $\quad$-------------- } \\
\hline \multirow{2}{*}{$25: 75$} & $20.9 c$ & $5.6 \mathrm{~b}$ & $2.03 \mathrm{c}$ & $1.28 \mathrm{~b}$ & $3.31 \mathrm{c}$ \\
\hline & $(2.98)$ & $(0.62)$ & $(0.35)$ & $(0.45)$ & $(0.79)$ \\
\hline \multirow{2}{*}{$50: 50$} & $27.1 \mathrm{bc}$ & $6.1 \mathrm{~b}$ & $3.72 b$ & $2.03 \mathrm{a}$ & 5.75 bc \\
\hline & $(3.21)$ & $(0.17)$ & $(0.34)$ & $(0.26)$ & $(0.27)$ \\
\hline \multirow{2}{*}{$75: 25$} & $31.6 \mathrm{ab}$ & $7.1 \mathrm{a}$ & $4.98 \mathrm{a}$ & $2.60 \mathrm{a}$ & $7.58 \mathrm{ab}$ \\
\hline & $(3.6 I)$ & $(0.83)$ & $(1.01)$ & $(1.54)$ & $(2.12)$ \\
\hline \multirow{2}{*}{$100: 00$} & $34.4 \mathrm{a}$ & $7.2 \mathrm{a}$ & $5.54 \mathrm{a}$ & $2.83 \mathrm{a}$ & $8.37 \mathrm{a}$ \\
\hline & $(2.60)$ & $(0.28)$ & $(0.27)$ & $(0.44)$ & $(0.67)$ \\
\hline
\end{tabular}

Values followed by the same letter in the columns do not differ from each other by the Tukey test $(P>0,95)$ and "ns" means non-significant.. 
According to data showed in Table 6, the content of macronutrients in plants shoot tissues did not differ between the treatments. The only exception was for $\mathrm{Ca}$, that was higher in the substrate with 75:25 (biosolids : coconut fiber) comparing it with 50:50 and 100:00. Although not significant, the mean content of $\mathrm{N}$ and $P$ in the aerial part of seedlings increased with the growing proportions of biosolids in the substrate, for $\mathrm{K}$ it decreased and for $\mathrm{Mg}$ it did not presented a pattern.

TABLE 6 Average and standard deviation (in parentheses) of macronutrients content $\left(\mathrm{g} \cdot \mathrm{kg}^{-1}\right)$ in the shoot of Ceiba speciosa seedlings produced in substrates with different proportions of biosolids and coconut fiber at 120 days after sowing.

\begin{tabular}{|c|c|c|c|c|c|}
\hline \multirow{2}{*}{$\begin{array}{c}\text { Treatments } \\
\text { (BIO\%:CF\%) }\end{array}$} & $\mathrm{N}$ & $P$ & $\mathrm{~K}$ & $\mathrm{Ca}$ & $\mathrm{Mg}$ \\
\hline & \multicolumn{5}{|c|}{ - } \\
\hline & $17.4 \mathrm{~ns}$ & $1.5 \mathrm{~ns}$ & $17.5 \mathrm{~ns}$ & $39.3 \mathrm{ab}$ & $4.0 \mathrm{~ns}$ \\
\hline 25 & (I. & (0. & $(0.3$ & (3.67) & $(0.39)$ \\
\hline 50.50 & 16. & 1.7 & 16. & 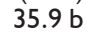 & ns \\
\hline טכ:כט & $(1.3$ & $(0.3$ & $(0.4$ & $(4)$. & $(0.70)$ \\
\hline $75 \cdot 2$ & 18. & 2.2 & 16. & 47. & $.5 \mathrm{~ns}$ \\
\hline 13.20 & $\begin{array}{r}(2.7 \mid \\
19.8\end{array}$ & $\begin{array}{l}(0.61) \\
2.2 \mathrm{~ns}\end{array}$ & $\begin{array}{c}(0.2 \\
16.9\end{array}$ & $\begin{array}{l}(4.60) \\
34.4 \mathrm{~b}\end{array}$ & $\begin{array}{l}(0.37) \\
4.9 \mathrm{~ns}\end{array}$ \\
\hline 0:0 & $(3.11)$ & $(0.30)$ & $(0.10)$ & $(4.99)$ & $(0.46)$ \\
\hline
\end{tabular}

Values followed by the same letter in the columns do not differ from each other by the Tukey test $(P>0,95)$ and "ns" means non-significant.

There were observed differences between substrates for the accumulated values. Generally, it increased along with the biosolids proportion for all macronutrients, except for $\mathrm{Ca}$, that showed higher accumulation in the 75:25 treatment (Table 7). The substrate with less biosolids (25:75) showed lower values for all the evaluated macronutrients.

TABLE 7 Average and standard deviation (in parentheses) of macronutrients accumulated ( $\mathrm{mg} \cdot$ seedling ${ }^{-1}$ ) in the shoot of Ceiba speciosa seedlings produced in substrates with different proportions of biosolids and coconut fiber at I 20 days after sowing.

\begin{tabular}{cccccc}
\hline Treatments & $\mathrm{N}$ & $\mathrm{P}$ & $\mathrm{K}$ & $\mathrm{Ca}$ & $\mathrm{Mg}$ \\
\cline { 2 - 6 } (BIO\%:CF\%) & ------------------ & mg·seedling & ------------- \\
\hline \multirow{2}{*}{$25: 75$} & $35.2 \mathrm{c}$ & $3.0 \mathrm{~b}$ & $35.5 \mathrm{c}$ & $79.9 \mathrm{~d}$ & $8.2 \mathrm{c}$ \\
& $(3.50)$ & $(0.23)$ & $(6.07)$ & $(7.45)$ & $(0.79)$ \\
$50: 50$ & $62.3 \mathrm{~b}$ & $6.5 \mathrm{~b}$ & $59.7 \mathrm{~b}$ & $133.6 \mathrm{C}$ & $18.4 \mathrm{~b}$ \\
& $(4.9 \mathrm{I})$ & $(1.1 \mathrm{I})$ & $(15.44)$ & $(16.08)$ & $(2.62)$ \\
$75: 25$ & $90.4 \mathrm{~b}$ & $11.0 \mathrm{a}$ & $81.0 \mathrm{ab}$ & $235.4 \mathrm{a}$ & $22.2 \mathrm{~b}$ \\
& $(13.50)$ & $(3.06)$ & $(13.00)$ & $(22.95)$ & $(1.86)$ \\
$100: 00$ & $109.7 \mathrm{a}$ & $12.2 \mathrm{a}$ & $93.8 \mathrm{a}$ & $190.6 \mathrm{~b}$ & $27.1 \mathrm{a}$ \\
& $(17.25)$ & $(1.65)$ & $(5.76)$ & $(27.65)$ & $(2.57)$ \\
\hline
\end{tabular}

Values followed by the same letter in the columns do not differ from each other by the Tukey test $(P>0,95)$.

The average macronutrient content followed the order $\mathrm{Ca}>\mathrm{N}>\mathrm{K}>\mathrm{Mg}>\mathrm{P}$, this pattern was observed for all treatments, except for the 25:75.

For the quality of $C$. speciosa seedlings the results were similar with the ones verified for growth and biomass (Table 8). Considering all the evaluated parameters, in general, the seedlings showed better quality in substrates with higher proportions of biosolids.
TABLE 8 Average and standard deviation (in parentheses) of height to diameter ratio $(H / D)$, height to shoot dry mass ratio (H/SDM), shoot dry mass to root dry mass ratio (SDM/RDM) and Dickson quality index (DQI) of Ceiba speciosa seedlings, I 20 days after sowing, produced in substrates with different proportions of biosolids and coconut fiber.

\begin{tabular}{ccccc}
\hline $\begin{array}{c}\text { Treatments } \\
\text { (BIO\%:CF\%) }\end{array}$ & $\mathrm{H} / \mathrm{D}$ & $\mathrm{H} / \mathrm{SDM}$ & $\mathrm{SDM} / \mathrm{RDM}$ & $\mathrm{DQI}$ \\
\hline \multirow{2}{*}{$25: 75$} & $3.74 \mathrm{~b}$ & $10.33 \mathrm{a}$ & $\mathrm{I} .66 \mathrm{~b}$ & $0.62 \mathrm{~b}$ \\
& $(0.12)$ & $(0.64)$ & $(0.28)$ & $(0.16)$ \\
& $4.42 \mathrm{a}$ & $7.34 \mathrm{~b}$ & $1.87 \mathrm{a}$ & $0.92 \mathrm{~b}$ \\
$50: 50$ & $(0.47)$ & $(1.10)$ & $(0.36)$ & $(0.05)$ \\
& $4.38 \mathrm{a}$ & $6.4 \mathrm{l} \mathrm{b}$ & $2.45 \mathrm{a}$ & $1.16 \mathrm{ab}$ \\
$75: 25$ & $(0.11)$ & $(0.68)$ & $(1.54)$ & $(0.49)$ \\
& $4.76 \mathrm{a}$ & $6.22 \mathrm{~b}$ & $1.98 \mathrm{a}$ & $1.25 \mathrm{a}$ \\
$100: 00$ & $(0.18)$ & $(0.53)$ & $(0.22)$ & $(0.16)$ \\
\hline
\end{tabular}

Values followed by the same letter in the columns do not differ from each other by the Tukey test $(P>0,95)$.

For $\mathrm{H} / \mathrm{D}$ significant difference was verified only for the 25:75 treatment, where the average value was lower than in the other treatments. In contrast with $H / D$, the $\mathrm{H} / \mathrm{SDM}$ ratio was lower in substrates with larger amounts of biosolids. Significant difference occurred only for the 25:75 treatment, that presented higher average value than the others.

For the SDM/RDM ratio, treatments with higher proportion of biosolids showed higher values. A significant difference was observed only for mean values of the 25:75 treatment, that was inferior than the others. The results for DQI followed the same trend observed for mostly of the other parameters, in which substrates with more biosolids showed better results.

\section{DISCUSSION}

Adding biosolids to substrates usually enhances the macronutrient content, as observed in this work and by Guerrini e Trigueiro (2004), Ribeiro et al. (2009), Faria et al. (2013) and other authors. The only exception was $\mathrm{K}$, which usually remains dissolved in the effluent from sewage treatment, resulting in low levels of it in the biosolids (Bettiol and Camargo, 2006). The main aim of mixing biosolids and coconut fiber in the present work was to provide $\mathrm{K}$ to the substrate, what in fact occurred, and can be observed for the 50:50 (biosolids : coconut fiber) and 75:25 treatments.

Regarding the physical characteristics, all treatments showed similar results in the evaluated parameters, except for density, that increased along with the proportion of biosolids in the substrate. The same pattern was observed for density by Guerrini e Trigueiro (2004), but the authors verified that adding biosolids to substrates also caused the increase of microporosity and 
water retention, as well as the decrease of macroporosity, aeration and draining capacity. These different results may be explained by the materials mixed with biosolids in each study, Guerrini e Trigueiro (2004) used carbonized rice husk and the present study used coconut fiber. The reduction of density and improvement of drainage were among the reasons for mixing biosolids and coconut fiber in the present study. The results demonstrate that the density reduction was achieved, but not the improvement of drainage, since all substrates showed similar values for macroporosity.

The shoot height is one of the main parameters applied to evaluate if forest seedlings are ready or not for planting (Carneiro, 1995). According to Moraes et al. (20/3) seedlings from Atlantic Forest tree species are ready to be planted when reach 25 to $30 \mathrm{~cm}$ of shoot height, considering that they are properly hardened. In this study, at 120 days after sowing, only seedlings from TI (25:75) did not reach the minimum height of $25 \mathrm{~cm}$ of the technical recommendation.

In Rio de Janeiro state, accordingly to the section 8 (4. I) of the State Environment Institute (INEA) Resolution No. 89/20I4 (INEA, 20I4) the seedling must have $60 \mathrm{~cm}$ of shoot height to be planted in forest restoration. As for the minimum height required by the state legislation no treatment achieved the necessary growth.

Studies in Rio de Janeiro state with planting of native species seedlings, as the one of Keller et al. (2009), showed survival above $90 \%$ at 60 days after planting for seedlings produced in different containers, considering that shoot height before planting were between 23.7 and 29 . I for Inga marginata and between 13.7 and $17.6 \mathrm{~cm}$ for Zeyheria tuberculosa. For seedlings of Enterolobium contortisiliquum produced in plastic bags of $9 \times 20 \mathrm{~cm}$ and tubes of $280 \mathrm{~cm}^{3}$, Abreu et al. (2015) observed mean height before planting of 73.3 and $28.3 \mathrm{~cm}$ respectively. The authors verified that the survival at 5 months after planting was of $100 \%$ for both treatments. Cabreira et al. (2017) produced Ceiba speciosa seedlings in $9 \times 20$ $\mathrm{cm}$ plastic bags using different proportion of biosolids in the substrate $(20,40,80 \%)$. Before planting, the authors observed shoot height of 23, 40 and $43 \mathrm{~cm}$ respectively for seedlings of each treatment. At five months after planting survival of seedlings were $100 \%$, regardless of the proportion of biosolids in the substrate and the seedlings height before planting.

The results of these studies show that planting seedlings with less than $60 \mathrm{~cm}$ of shoot height and within the value $(25$ to $30 \mathrm{~cm}$ ) recommended by Moraes et al. (20I3) can be viable for restoration of Atlantic Forest.
It should be noted that, on the contrary to what it is stated in INEA Resolution No. 89/20I4 (INEA, 2014), the height should not be used alone as an indicator of quality or that seedlings are ready to be planted, other parameters must be considered together with height (Davide et al., 20I5).

The root collar diameter is considered as a measure of the vigor and sturdiness of the seedlings, being related to their growth after planting, as well as with their resistance to adverse climatic conditions, like heat and drought (Carneiro, 1995; Grossnickle, 2012; Grossnickle and Macdonald, 2018). In the study of Tsakaldimi et al. (2013) the diameter was the morphological parameter that more accurately could predict outplanting survival. Gonçalves et al. (2000) states that the adequate values for root collar diameter should stay between 5 to $10 \mathrm{~mm}$ for seedlings from Atlantic Forest tree species, considering this recommendation all evaluated treatments produced seedlings suitable for planting.

For both shoot height and root collar diameter the addition of biosolids in the substrate, in proportions of 50 to $100 \%$, presented significant higher growth of the seedlings. The recommendations regarding the proportion of biosolids in substrate to produce native species seedlings are variable. In the study of Kratz et al. (20I5) only small proportions (I0 to $20 \%$ ) of biosolids in the substrate were viable to produce Mimosa scabrella seedlings. Other studies recommend values between 40 to $80 \%$ for different species (Caldeira et al., 20I2; Faria et al., 20I3; Delarmelina et al., 20I4; Trigueiro and Guerrini, 20I4). In the present work the best results were obtained in substrates with 75 and $100 \%$ of biosolids.

The result of the present and other experiments indicates that the adequate proportion of biosolids in the substrate can vary, among other factors, accordingly to the requirements and characteristics of each forest species. Generally, it is viable to produce seedlings from Atlantic Forest tree species in plastic tubes of $280 \mathrm{~cm}^{3}$ and with biosolids proportions of 50 to $100 \%$ in the substrate, giving a more sustainable end to this material when comparing with landfill disposal.

It is necessary to consider that chemical and physical characteristics of biosolids are also determinant factors for the proportion in which this material can be used as substrate. The occurrence of salinity and the presence of elements that can be toxic to plants, as well as a high density or low porosity, can restrict or even make it impossible to use biosolids in the substrate for seedlings production (Guerrini and Trigueiro, 2004; Mañas et al., 2009; Ribeiro et al., 2009; Kratka and Correia, 2015). 
These characteristics of biosolids are variable according with the collection season, the sewage treatment done in each WWTP, the processes by which the sludge is stabilized and benefited inside and outside the WWTP, among other factors (Andreoli et al., 20I4; Abreu et al., 20I7).

Regarding the physical characteristics of substrates, the aggregation of roots to the substrate and the ease of removing the seedling from the container should also be considered. Trigueiro and Guerrini (2003) stated that, for Eucalyptus grandis seedlings, roots aggregation was worse in substrates with higher proportions of biosolids (60 and $80 \%$ ), similar results were observed by Kratz et al. (20I5) for Mimosa scabrella. "In the proportion of $80 \%$ of biosolids, Trigueiro and Guerrini (2003) also verified that the extraction of seedlings from the container was prejudicated. In the present study these parameters were not evaluated, but considering the observations done during the experiment, even in the substrate with $100 \%$ of biosolids, roots aggregation and ease of container removal were adequate. Corroborating with the present work, Siqueira et al. (2018) observed the same aggregation in commercial substrate and in substrate with $100 \%$ biosolids, for Lafoensia glyptocarpa seedlings.

Based in the results for growth (Figures I and Table 5) and biomass (Table 5) of the seedlings, as well as the chemical (Table 3) and physical (Table 4) characteristics of the evaluated substrates, it is possible to state that the treatment of sewage from urban residential and commercial areas, by the activated sludge process, followed by the anerobic digestion of the sludge and drying in outdoor beds, results in biosolids with good aptitude for recycling in the production of forest seedlings.

The highest total biomass observed in the seedlings produced with higher proportions of biosolids in the substrate are reasonable, considering the results obtained for growth on height and diameter. The investment in shoot biomass was higher than in roots biomass, what was more evident in substrates with higher proportions of biosolids, which can be attributed to the higher among of nutrients, mainly $\mathrm{N}$ and $\mathrm{P}$, in these substrates. The importance of these nutrients in the initial growth of the seedlings shoot is mentioned by Faria et al. (20I3), which attributed the highest shoot growth and biomass of Senna alata in a substrate with $80 \%$ biosolids and $20 \%$ coconut fiber to the $\mathrm{N}$ and $\mathrm{P}$ contents in this substrate.

Although the content of $\mathrm{N}$ and $\mathrm{P}$ in aerial biomass of $C$. speciosa were similar in all treatments, these nutrients accumulation were higher in substrates that contained biosolids. The higher accumulation of nutrients in the aerial biomass of $C$. speciosa seedlings produced in substrates with higher proportions of biosolids can be attributed to the higher content of these nutrients in this material, which resulted in higher growth of the seedlings. Similar results were observed by Scheer et al. (2012), comparing two composts made with biosolids and pruning residues with a commercial substrate, the authors verified higher content of macro and micronutrients in substrates with biosolids, resulting in higher $\mathrm{N}, \mathrm{P}$ and $\mathrm{K}$ accumulated in the leaf biomass and higher growth of Lafoensia pacari seedlings produced with both composts.

The concentration of $\mathrm{K}$ in biosolids is usually low, considering that it is a highly soluble element that is diluted and solubilized in wastewater (Andreoli et al., 2014). Considering that the coconut fiber was rich in $\mathrm{K}$ and the biosolids in $\mathrm{N}$ and $\mathrm{P}$ (Table I), it was expected that mixing these materials would result in a substrate with better chemical characteristics. However, the content of $\mathrm{K}$ in plants tissues was similar in all treatments, which suggests that the amount of this nutrient in the biosolids was enough to supply the demand of seedlings of $C$. speciosa, dismissing the need of complementary fertilization.

The height and diameter ratio $(H / D)$, also called sturdiness index or quotient, represents how much the seedling grew in height $(\mathrm{cm})$ in relation to its growth in diameter $(\mathrm{mm})$ (Gomes and Paiva, 2006). High values of $H / D$ ratio indicate the stretching of the seedlings, compromising their quality. It is recommended for seedlings of silvicultural species, like Pinus sp. and Eucalyptus sp., values between 5.4 and 8.1 for the H/D ratio (Carneiro, 1995). For Atlantic Forest species there is no reference value established.

The values of $H / D$ ratio observed for $C$. speciosa in the present study were bellow the minimum recommended (5.4) in all treatments. The values can also be considered low when compared to the ones observed for other native tree species (Abreu et al., 2015; Delamerlina et al., 2014; Keller et al., 2009; Caldeira et al., 2008). This result can be explained by the peculiar thickening that occur close do the base of the stem in this species, which can be observed in adult trees and in the seedlings in a lesser extent, giving it popular names such as "barriguda" (paunchy) and barriga d'água" (water belly) (Carvalho, 2003). Considering these aspects, the results for $H / D$ suggests that all treatments produced good quality seedlings, with better results in substrates with higher proportions of biosolids.

For the parameter $\mathrm{H} / \mathrm{SDM}$, high values indicate that seedlings had grown without accumulating biomass, which can happen due to seedlings stretching or low leaf 
production, which can result in a lower photosynthetic potential. The lower the value of H/SDM the better the quality of the seedlings will be (Gomes and Paiva, 2006), thus in the present study it was observed that substrates with higher proportions of biosolids resulted in seedlings with better quality.

The distribution of biomass in the seedlings can be represented by the ratio between shoot and root dry mass (SDM/RDM). This parameter is related with the seedlings water balance, where high values can indicate that seedlings are more vulnerable to water stress, considering the inequality between their transpiration surface (shoot) and their potential to absorb water (roots) (Grossnickle, 2012). Low values of this ratio may indicate deficient foliage development, negatively influencing photosynthesis (Mañas et al., 2009). Caldeira et al. (2008) and Gomes and Paiva (2006) recommends that good quality seedlings should present values around 2.0 for this ratio. In the present study it was observed that the substrate with $100 \%$ of biosolids was the one with values closest to the recommendation, thus, for this parameter, it can be considered the treatment that provided the seedlings with the best quality.

In substrates with 25 and $50 \%$ of biosolids the values of SDM/RDM were lower than the technical recommendation (2.0), indicating higher proportion of roots in these treatments.

The Dickson quality index (IQD) is calculated using the most important parameters applied in the evaluation of seedlings quality (shoot height, root collar diameter, shoot and root biomass). The higher the value of this index, the more balanced the growth of seedlings is and the better could be considered its quality (Carneiro, 1995). For seedlings of species used in commercial silviculture it is recommended values of IQD above 0.2 (Carneiro, 1995; Gomes and Paiva, 2006). For Atlantic Forest and other native Brazilian and Latin American species the existent data is insufficient, which demands studies to calibrate the ideal value of this parameters for different species.

The values of IQD observed for C. speciosa in the present study were lower than the ones obtained in other studies, like Cabreira et al. (2017), who evaluated seedlings production in plastic bags until 120 days and their planting, observing IQD values between I,35 and I,84 and survival between 95 and $100 \%$ at five months after planting. In larger recipient seedlings tends to show higher growth and consequently higher IQD, like it was observed by Leles et al. (2006) for seedlings of four native species, among then the $C$. speciosa, which presented IQD values of I.80, 2.36,
4.05 and 3.54 respectively for plastic tubes with volumes of $56,115,180$ and $280 \mathrm{~cm}^{3}$ in seedlings produced in 180 days. However, in the study of Cabreira et al. (2017) the seedlings were produced in larger recipients than the ones used by Leles et al. (2006) and IQD values for $C$. speciosa were lower, which can be explained by how long the seedling production in each study was. Cabreira et al. (2017) produced the seedlings in 120 days and in Leles et al. (2006) the production took 180 days, that is 60 days longer than the previous and the present study.

Considering that, among other factors, the morphological characteristics of forest seedlings can vary depending on the container, substrate, fertilization, irrigation and seedlings age (Davide et al., 20I5), the differences between results of the present and other studies can be justified. It is possible to estimate that if seedlings of the present study stayed in the nursery for a longer time, they would have reached higher values of IQD, probably near the ones observed by Cabreira et al. (2017) and Leles et al. (2006). However, it is believed that at 120 days after sowing seedlings of the present work showed quality enough to be planted. The quality of forest seedlings should be assessed based on a group of parameters, not only one (Carneiro, 1995; Davide et al., 20I5). Besides, the ideal values of IQD, as well as other parameters, could vary accordingly to the produced species, the techniques used in the nursery, planting site quality, planting time, among other factors (Carneiro, 1995; Caldeira et al., 2012). There were not found for comparison other studies were C. speciosa seedlings, with IQD values equal or lower than the ones observed in the present study, were planted to evaluate their growth and survival. This confirms the need for studies evaluating the utilization of this and other parameters to assess the quality of forest species seedlings.

\section{CONCLUSION}

Higher proportions of biosolids in the substrate resulted in higher quality and growth of seedlings of Ceiba speciosa (A. St.-Hil.) Ravenna. Considering all the evaluated parameters, the seedlings produced in substrates composed of 50 to $100 \%$ of biosolids, at 120 days after sowing in $280 \mathrm{~cm}^{3}$ plastic tubes, presented enough quality to be planted in site.

\section{REFERENCES}

ABREU, A. H. M.; LELES, P. S. S.; ALONSO, J. M.; ABEL, E. L. S.; OLIVEIRA, R. R. Characterization of sewage sludge generated in Rio de Janeiro, Brazil, and perspectives for agricultural recycling. Semina: Ciências Agrárias, v.38, n. 4, p. 2433-2448, 2017. 
ABREU, A. H. M.; LELES, P. S. S.; MELO, L. A.; FERREIRA, D. H. A. A.; MONTEIRO, F.A. S.. Produção de mudas e crescimento inicial em campo de Enterolobium contortisiliquum produzidas em diferentes recipientes. Floresta, v.45, n.I, p.I4I-I50, 2015.

ANDREOLI, C. V.; SPERLING, M. V.; FERNANDES, F. Lodo de esgotos: tratamento e disposição final. Belo Horizonte: Editora UFMG, 20I4. 444 p.

BRASIL. Ministério do Meio Ambiente. Conselho Nacional do Meio Ambiente (CONAMA). Resolução n 375/2006. Define critérios e procedimentos para o uso agrícola de lodos de esgoto gerados em estações de tratamento de esgoto sanitário e seus produtos derivados. Diário Oficial da República Federativa do Brasil, Brasília, 30 ago 2006, n. I67, p. |4|-|46.

CABREIRA, G. V.; LELES, P. S. S.; ALONSO, J. M.; ABREU, A. H. M.; LOPES, N. F.; SANTOS, G. R. Biossólido como componente de substrato para produção de mudas florestais. Floresta, v.47, n. 2, p. 165-176, 2017 a.

CALDEIRA, M. V. W.; PERONI, L.; GOMES, D. R.; DELARMELINA, W. M.; TRAZZI, P. A. Diferentes proporções de biossólido na composição de substratos para a produção de mudas de timbó (Ateleia glazioveana Baill). Scientia Forestalis, v. 40, n. 93, p. 0I5-022, 2012.

CALDEIRA, M. V. W.; ROSA, G. N.; FENILLI, T. A. B.; HARBS, R. M. P. Composto orgânico na produção de mudas de aroeiravermelha. Scientia Agraria, v. 9, n. I, p. 27-33, 2008.

CARNEIRO, J. G. A. Produção e controle de qualidade de mudas florestais. Curitiba: Editora UFPR/FUPEF, 1995. 45 I $\mathrm{p}$

CARVALHO, C. M.; SILVA, C. R. Determinação das propriedades físicas de substrato. Notas de aulas práticas. Botucatu: Universidade Estadual Paulista, 1992. 6p.

CARVALHO, P. E. R. Espécies Arbóreas Brasileiras, Volume I. Colombo: Embrapa Florestas, 2003. 1039p.

DAVIDE, A. C.; MELO, L. A.; TEIXEIRA, L. A. F.; PRADO, N. J. S.; FIORINE, R. A.; CARVALHO, R. P. Fatores que afetam a qualidade de mudas destinadas aos projetos de restauração de ecossistemas florestais. In: DAVIDE, A. C.; BOTELHO, S. A. Fundamentos e métodos de restauração de ecossistemas florestais: 25 anos de experiência em matas ciliares. Lavras: Editora UFLA, 2015. 636p.

DELARMELINA, W. M.; CALDEIRA, M. V. W.; FARIA, J. C. T.; GONÇALVES, E. O.; ROCHA, R. L. F. Diferentes substratos para a produção de mudas de Sesbania virgata. Floresta e Ambiente, v. 21, n. 2, p. 224-233, 2014.

EMBRAPA. Manual de análises químicas de solos, plantas e fertilizantes. Brasília: Embrapa Informação Tecnológica, 2009. 627p.
FARIA, J. C. T.; CALDEIRA, M. V. W.; DELARMELINA, W. M.; LACERDA, L. C.; GONÇALVES, E. O. Substratos à base de lodo de esgoto na produção de mudas de Senna alata. Comunicata Scientiae, v.4, n.4, p.342-35I, 2013.

GOMES, J. M.; PAIVA, H. N. Viveiros florestais (propagação sexuada). Viçosa: Editora UFV, 2006. 116 p

GONÇALVES, J. L. M., SANTERELLI, E. G., NETO, S. P. M., MÁNARA, M. P. 2000. Produção de mudas de espécies nativas: substrato, nutrição, sombreamento e fertilização. In: Gonçalves, J.L.M., Benedetti, V. Nutrição e fertilização florestal. ESALQ/USP, Piracicaba, Brasil. p. 309- 350.

GROSSNICKLE, S. C. Why seedlings survive: influence of plants attributes. New Forests, v.43, p. 7I I-738, 2012.

GUERRINI, I. A.; TRIGUEIRO, R. M. Atributos físicos e químicos de substratos compostos por biossólidos e casca de arroz carbonizada. Revista Brasileira de Ciência do Solo. Viçosa, v. 28, p. 1069-1076, 2004.

RIO DE JANEIRO. Instituto Estadual do Ambiente (INEA). Resolução $n^{\circ} 89 / 2014$. Dispõe sobre as proporções mínimas aplicáveis para reposição florestal, decorrentes do corte ou supressão de vegetação pertencente às formações florestais nativas e ecossistemas associados do Bioma Mata Atlântica, bem como de intervenções em Áreas de Preservação Permanente - APP, para fins de Licenciamento Ambiental e/ou de Autorização para Supressão de Vegetação Nativa - ASV no Estado do Rio de Janeiro. Diário Oficial do Estado do Rio de Janeiro, Rio de Janeiro, 05 jun 20I4, n. I0I, p. 22-24.

KELLER, L.; LELES, P.S.S; OLIVEIRA NETO, S.N.; COUTINHO, R.P.; NASCIMENTO, D.F. Sistema de blocos prensados na produção de mudas de espécies arbóreas. Revista Árvore, v.33, n.2, p.305-3|4, 2009.

KLIPPEL, V. H.; PEZZOPANE, J. E. M.; SILVA, G. F.; CALDEIRA, M. V. W.; PIMENTA, L. R.; TOLEDO, J. V. Avaliação de métodos de restauração florestal de mata de taboleiros ES. Revista Árvore, v.39, n. I, p.69-79, 2015.

KRATKA, P. C.; CORREIA, C. R. M. A. Crescimento inicial de aroeira do sertão (Myracrodroun urundeuva Allemão) em diferentes substratos. Revista Árvore, v.39, n.3, p.55I-559, 2015.

KRATZ, D.; NOGUEIRA, A. C.; WENDLING, I.; SOUZA, P. V. D. Substratos renováveis para produção de mudas de Mimosa scabrella. Floresta, v. 45, n. 2, p. 393-408, 2015.

LELES, P. S. S.; LISBOA, A. C.; OLIVEIRA NETO, S. N.; GRUGIKI, M. A.; FERREIRA, M. A. Qualidade de mudas de quatro espécies florestais produzidas em diferentes tubetes. Floresta e Ambiente, v. I3, n. I, p. 69-78, 2006.

MAÑAS, P.; CASTRO, E.; HERAS, J. Quality of marritime pine (Pinus pinaster Ait.) seedlings using waste materials as nursery growing media. New Forests, v. 37, n. 3, p. 295-3 I I, 2009.

MORAES, L.F.D., ASSUMPÇÃO, J.M., PEREIRA, T.S., LUCHIARI, C. Manual técnico para a restauração de áreas degradadas no Estado do Rio de Janeiro. Rio de Janeiro: Instituto de Pesquisas Jardim Botânico do Rio de Janeiro. 20I3. 84p. 
RIBEIRO, H. M.; VASCONCELOS, E.; CABRAL, F. Fertilization of Pinus pinea L. seedlings with a sewage sludge-based compost. Waste Management \& Research, v.27, n.l, p.II2-II8, 2009.

SAEG. Sistema para Análises Estatísticas e Genéticas: Versão 9. I. Fundação Arthur Bernardes - UFV: Viçosa, 2007.

SCHEER, M. B.; CARNEIRO, C.; BRESSAN, O. A.; SANTOS, K. G. Crescimento e nutrição de mudas de Lafoensia pacari com lodo de esgoto. Floresta e Ambiente, v. 19, n. I, p.55-65, 2012.

SIQUEIRA, D. P.; CARVALHO, G. C. M. W.; BARROSO, D. G.; MARCIANO, C. R. Lodo de esgoto tratado na composição de substrato para produção de mudas de Lafoensia glyptocarpa. Floresta, v.48, n.2, p.277-284, 2018.
SOS MATA ATLÂNTICA; INPE. Atlas dos Remanescentes Florestais da Mata Atlântica - Período 2016-2017. São Paulo: Fundação SOS Mata Atlântica. 2018. 63p.

TRIGUEIRO, R. M.; GUERRINI, I. A. Uso de biossólido como substrato para produção de mudas de eucalipto. Scientia Forestalis, v.64, n. I, p. 150-162, 2003.

TRIGUEIRO, R. M.; GUERRINI, I. A. Utilização de lodo de esgoto na produção de mudas de aroeira-pimenteira. Revista Árvore, v. 38, n. 4, p. 657-665, 2014.

TSAKALDIMI, M.; GANATSAS, P.; JACOBS, D. F. Prediction of planted seedling survival of five Mediterranean species based on initial seedling morphology. New Forests, v.44, n. I, p.327-339, 2013. 